Article

\title{
Phenolics and Carotenoid Contents in the Leaves of Different Organic and Conventional Raspberry (Rubus idaeus L.) Cultivars and Their In Vitro Activity
}

\author{
Alicja Ponder and Ewelina Hallmann * \\ Department of Functional and Organic Food, Institute of Human Nutrition, Warsaw University of Life Sciences, \\ Nowoursynowska 159c, 02-776 Warsaw, Poland; alicja_ponder@sggw.pl \\ * Correspondence: ewelina_hallmann@sggw.pl; Tel.: +48-22-593-7036
}

Received: 29 August 2019; Accepted: 4 October 2019; Published: 7 October 2019

\begin{abstract}
Raspberry leaves are a source of carotenoids and polyphenols, including ellagic acid and salicylic acid. The results of scientific research suggest that they have potential pro-health properties that contribute to human health. The aim of this study was to determine the polyphenolic and carotenoid profiles in the leaves of selected raspberry cultivars and their in vitro activity. The second aim was to determine the impact of organic and conventional farm management on the polyphenol, carotenoid, and chlorophyll contents in different raspberry cultivars: 'Polana', 'Polka', 'Tulameen', 'Laszka' and 'Glen Ample'. Compared with conventional raspberry leaves, organic raspberry leaves were characterized by a significantly higher content of dry matter, total polyphenols, total phenolic acids, chlorogenic acid, caffeic acid, salicylic acid and quercetin-3-O-rutinoside; moreover, the organic leaves were characterized by higher antioxidant activity. Among examined cultivars, 'Polka' c. was characterized by the highest antioxidant status. However, raspberry leaves from conventional farms contained more total carotenoids, violaxanthin, alpha-carotene, beta-carotene, total chlorophyll and individual forms of chlorophylls: $a$ and $b$.
\end{abstract}

Keywords: raspberry leaves; phenolics; carotenoids; antioxidant activity; organic; conventional

\section{Introduction}

Raspberry (Rubus ideaus) is recognized by consumers as a tasty and healthy fruit. Recent research indicates that the leaves of berry plants, such as strawberries, raspberries, blueberries and blackcurrants, are a potential source of bioactive compounds with strong, pro-health, anticancer and anti-inflammatory properties [1-4]. Berry leaves are by-products of berry plant cultivation. Their traditional therapeutic use against several diseases, such as the common cold, inflammation, diabetes, and ocular inflammation, has been almost forgotten [5]. Raspberry leaves contain high amounts of polyphenols and can serve as a potential source of natural antioxidants for medicinal and commercial uses. Raspberry leaves contain phenolic acids, such as chlorogenic, gallic, ferulic, caffeic acids, as well as flavonoids, including quercetin and kaempferol-3-O-glucosiden [6]. However, two chemical compounds deserve special attention: ellagic and salicylic acids $[7,8]$. These compounds show strong biological effects in vitro that have been connected to pharmacological and nutritional effects [9]. They are mainly related to the prevention of cardiovascular diseases [10]. Many current medicines are derived from plants, including aspirin, which is a synthetic derivative of salicylic acid [11,12]. Plants produce salicylic acid as a response to biotic (pest and diseases) stresses $[13,14]$.

Many studies have shown that organic cultivation methods increase the amount of bioactive compounds in fruits [15-17], mostly due to the effect of plant self-protection against pest and diseases. The latest research with raspberry fruit indicates that organic fruit contained significantly more 
polyphenols compare to conventional one fruits [18]. Phenolic compounds are well known as "natural pesticides". In organic agriculture, plants produce more phenolic compounds in the leaves because use of synthetic pesticides is forbidden $[19,20]$. In the present experiment, the authors want to investigate how cultivation methods effect the content of biologically active compounds in raspberry leaves.

The main goal of the study was to determine the polyphenol, carotenoid and chlorophyll profile in leaves of selected raspberry cultivars. The second aim was to determine the impact of farm management on the bioactive compound contents in different raspberry leaves cultivars.

\section{Materials and Methods}

\subsection{Plants Origin}

The experiment was carried out in 2013. Leaves of five raspberry cultivars ('Polana', 'Polka', 'Tulameen', Laszka' and 'Glen Ample') were collected at the time of cultivation. Three organic and neighborhood conventional farms were used for experimental purposes. From one cultivar (one field plot), 3-4 plants were chosen, which were analyzed separately. One sample consisted of 10 leaves. The farm was treated as a replication. Detailed information about the agricultural conditions and practices in experimental farms is presented in Table 1 and Figure 1.

Table 1. Characterization of localization, fertilizers regime and plant protection used for organic and conventional raspberry. Cultivation in 2013 year.

\begin{tabular}{|c|c|c|c|c|c|}
\hline $\begin{array}{l}\text { Cultivation } \\
\text { System }\end{array}$ & Localization & Type of Soil & Kind of Fertilizer & $\begin{array}{c}\text { Dose of Fertilizers and Time } \\
\text { of Given }\end{array}$ & $\begin{array}{l}\text { Plant } \\
\text { Protection } \\
\text { System }\end{array}$ \\
\hline $\begin{array}{l}\text { organic farm } \\
\text { no. } 1\end{array}$ & $\begin{array}{l}\text { Zakroczym } \\
\left(52^{\circ} 26^{\prime \prime} \mathrm{N}\right. \\
\left.20^{\circ} 36^{\prime \prime} \mathrm{E}\right)\end{array}$ & $\begin{array}{c}\text { sandy middle soil IVa and IVb } \\
\text { category (15\% floatable } \\
\text { particles) pH } 5.5\end{array}$ & cow manure & $\begin{array}{l}35 \mathrm{tha}^{-1} \text { one year before } \\
\text { raspberry planting }\end{array}$ & Grevit 200 SL \\
\hline $\begin{array}{l}\text { organic farm } \\
\text { no. } 2\end{array}$ & $\begin{array}{c}\text { Załuski } \\
\left(52^{\circ} 37^{\prime \prime} \mathrm{N}\right. \\
\left.20^{\circ} 22^{\prime \prime} \mathrm{E}\right)\end{array}$ & $\begin{array}{l}\text { sandy middle soil, sandy-clay } \\
\text { IV category ( } 20 \% \text { floatable } \\
\text { particles), pH } 5.5\end{array}$ & cow manure & $\begin{array}{l}30 \mathrm{tha}^{-1} \text { one year before } \\
\text { raspberry planting }\end{array}$ & no protection \\
\hline $\begin{array}{l}\text { organic farm } \\
\text { no. } 3\end{array}$ & $\begin{array}{l}\text { Radzanów } \\
\left(51^{\circ} 33^{\prime \prime} \mathrm{N}\right. \\
\left.20^{\circ} 51^{\prime \prime} \mathrm{E}\right)\end{array}$ & $\begin{array}{l}\text { sandy middle soil IVa and III } \\
\text { category ( } 10 \% \text { floatable } \\
\text { particles), pH } 6.0\end{array}$ & $\begin{array}{l}\text { sheep manure, } \\
\text { green manure }\end{array}$ & $\begin{array}{l}10 \mathrm{tha}^{-1} \text { and } 15 \mathrm{tha}^{-1} \text { one } \\
\text { year before raspberry planting, }\end{array}$ & $\begin{array}{l}\text { Bioczos } 33 \text { SL, } \\
\text { Grevit } 200 \text { SL }\end{array}$ \\
\hline $\begin{array}{l}\text { conventional } \\
\text { farm no. } 1\end{array}$ & $\begin{array}{c}\text { Czerwińsk nad } \\
\text { Wisła } \\
\left(52^{\circ} 23^{\prime \prime} \mathrm{N}\right. \\
\left.20^{\circ} 20^{\prime \prime} \mathrm{E}\right)\end{array}$ & $\begin{array}{l}\text { sandy-loamy middle soil IV } \\
\text { and III category ( } 20 \% \text { floatable } \\
\text { particles), pH } 5.5\end{array}$ & $\begin{array}{c}\text { Hydrocomplex } \\
\text { 12-11-18; Superba } \\
\text { 8-11-36 }\end{array}$ & $\begin{array}{l}\left(200 \mathrm{~kg} \mathrm{ha}^{-1}, 150 \mathrm{~kg} \mathrm{ha}^{-1}\right) \text { in } \\
\text { autumn a year before } \\
\text { raspberry planting; } 3 \text { doses in } \\
\text { time of cultivation }\end{array}$ & $\begin{array}{l}\text { Signum } 33 \text { WG, } \\
\text { Miros } 20 \mathrm{SP},\end{array}$ \\
\hline $\begin{array}{l}\text { conventional } \\
\text { farm no. } 3\end{array}$ & $\begin{array}{l}\text { Czerwińsk nad } \\
\text { Wisła } \\
\left(52^{\circ} 25^{\prime \prime} \mathrm{N}\right. \\
\left.20^{\circ} 23^{\prime \prime} \mathrm{E}\right)\end{array}$ & $\begin{array}{l}\text { sandy-clay middle soil II and } \\
\text { III category ( } 20 \% \text { floatable } \\
\text { particles) } \mathrm{pH} 6.0\end{array}$ & Rosafert 5-12-24-3 & $\begin{array}{l}250 \mathrm{~kg} \mathrm{ha}^{-1} \text { in autumn a year } \\
\text { before raspberry planting; } \\
4 \text { doses in time of cultivation }\end{array}$ & $\begin{array}{l}\text { Calypso } 480 \mathrm{SC}, \\
\text { Miros } 20 \mathrm{SP}, \\
\text { Zato } 50 \mathrm{WG}\end{array}$ \\
\hline
\end{tabular}
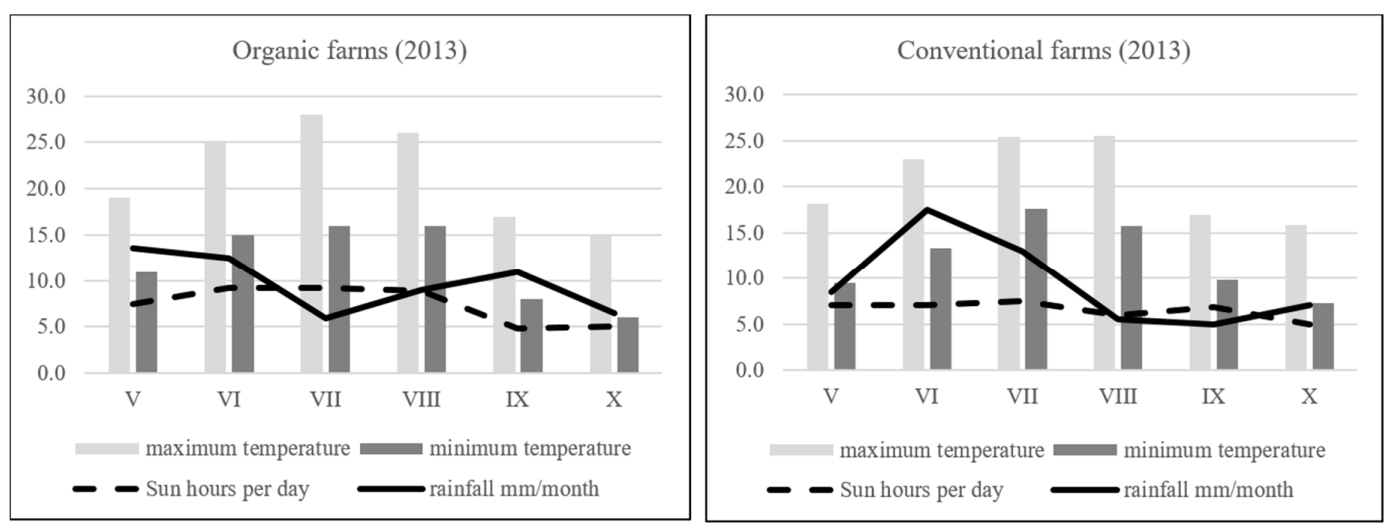

Figure 1. Weather conditions at the experimental farms (organic and conventional) in time of raspberry leaves experiment. 


\subsection{Plant Material Preparation}

The leaves for chemical analysis were harvested early in the morning from each production farm and immediately transported to the laboratory. Each sample was divided into two parts. The first part was used for dry matter evaluation, and the second part was freeze-dried using a Labconco (2.5) freeze-dryer (Warsaw, Poland, $-40^{\circ} \mathrm{C}$, pressure $0.100 \mathrm{mBa}$ ). After freeze-drying, the plant material was ground in a laboratory mill (A-11). The ground samples were then stored at $-80^{\circ} \mathrm{C}$.

\subsection{Dry Matter Content}

The dry matter content of the raspberry leaves was measured before freeze-drying. The dry matter content was determined using the weight method. Empty glass beakers were weighed, filled with fresh leaves and weighed again. The samples were dried at $105^{\circ} \mathrm{C}$ for $72 \mathrm{~h}$ in an FP-25W Farma Play (Tczew, Poland) dryer. After 3 days, the samples were cooled to $21^{\circ} \mathrm{C}$ and weighed. The dry matter content was calculated for the leaf samples based on their mass differences and given in units of $100 \mathrm{~g}^{-1}$ FW (fresh weight) [21].

\subsection{Phenolic Acid and Flavonol Separation and Identification}

Polyphenols were measured by an HPLC (High Performance Liquid Chromatography) method that was described previously in detail by Hallmann et al. [22]. A total of $100 \mathrm{mg}$ of freeze-dried, powdered plant material was mixed with $5 \mathrm{~mL}$ of $80 \%$ methanol and shaken on a Micro-Shaker $326 \mathrm{M}$ (Marki, Poland). Next, all samples were extracted in an ultrasonic bath $\left(10 \mathrm{~min}, 30^{\circ} \mathrm{C}, 5500 \mathrm{~Hz}\right)$. After $10 \mathrm{~min}$ of extraction, the leaf samples were centrifuged $\left(10 \mathrm{~min}, 3780 \times g, 5^{\circ} \mathrm{C}\right)$. The supernatant was collected in a clean plastic tube and centrifuged again $\left(5 \mathrm{~min} ; 31,180 \times g, 0^{\circ} \mathrm{C}\right)$. A total of $900 \mu \mathrm{L}$ of supernatant was transferred to an HPLC vial and analysed. For polyphenol compound separation and identification, a Synergi Fusion-RP 80i Phenomenex column $(250 \times 4.60 \mathrm{~mm})$ was used. The analysis was carried out with the use of Shimadzu equipment (USA Manufacturing Inc, Lebanon, IN, USA: two pumps LC-20AD, controller CBM-20A, column oven SIL-20AC, spectrometer UV/Vis SPD-20 AV). The phenolic compounds were separated under gradient conditions with a flow rate of $1 \mathrm{~mL} \mathrm{~min}^{-1}$. Two gradient phases were used: $10 \%(V: V)$ acetonitrile and ultrapure water (phase A) and 55\% $(V: V)$ acetonitrile and ultrapure water (phase B). The phases were acidified by orthophosphoric acid (pH 3.0). The total time of the analysis was $38 \mathrm{~min}$. The phase-time programme was as follows: $1.00-22.99 \mathrm{~min}$, 95\% phase $A$ and $5 \%$ phase $B ; 23.00-27.99 \mathrm{~min}, 50 \%$ phase $A$ and $50 \%$ phase $\mathrm{B} ; 28.00-28.99 \mathrm{~min}, 80 \%$ phase $A$ and $20 \%$ phase $B$; and $29.00-38.00 \mathrm{~min}, 95 \%$ phase $A$ and $5 \%$ phase $B$. The wavelengths were $250 \mathrm{~nm}$ for flavonols and $370 \mathrm{~nm}$ for phenolic acids. The phenolic compounds were identified by using 99.9\% pure standards (Sigma-Aldrich, Szelagowska, Poland) and the analysis times for the standards (Figures 2 and 3).
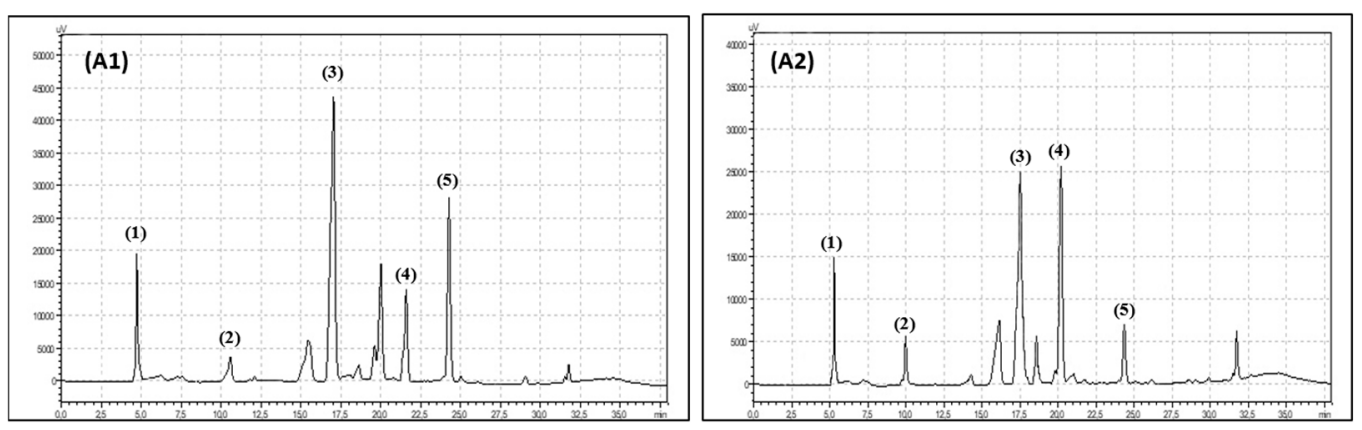

Figure 2. Chromatogram showing retention times for organic raspberry (A1) and conventional raspberry leaves (A2) phenolic acids: (1) chlorogenic acid, (2) caffeic acid, (3) salicylic acid, (4) p-coumaric acid, (5) ellagic acid. 

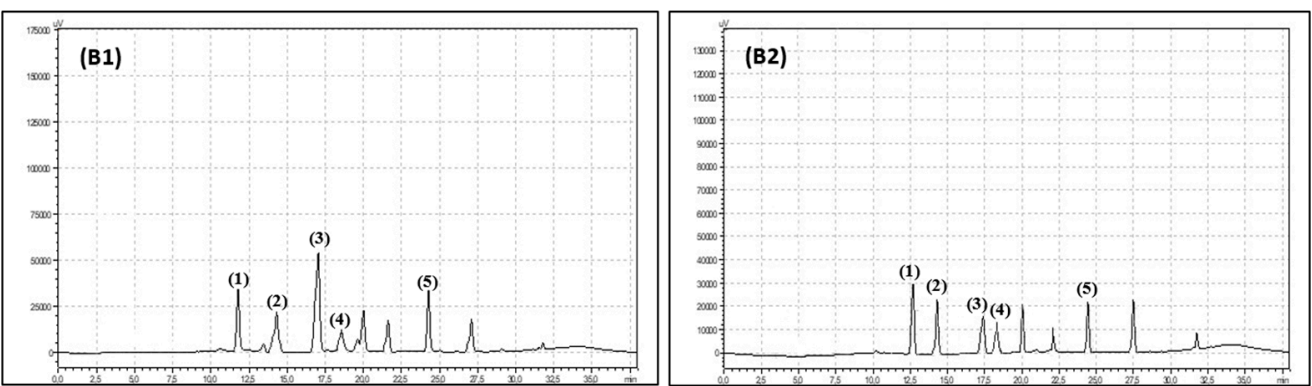

Figure 3. Chromatogram showing retention times for organic raspberry (B1) and conventional raspberry leaves (B2) flavonoids: (1) quercetin-3-O-rutinoside, (2) myrycetin, (3) quercetin-3-O-glucoside, (4) quercetin, (5) luteolin.

\subsection{Carotenoid and Chlorophyll Separation and Identification}

Carotenoids and chlorophylls were measured by an HPLC method, as described by Hallmann et al. [22]. Sample preparation included extraction of $100 \mathrm{mg}$ of freeze-dried sample with $100 \%$ acetone using an ultrasonic cold bath $\left(10 \mathrm{~min}, 0^{\circ} \mathrm{C}\right)$. Samples were then centrifuged $(10 \mathrm{~min}, 3780 \times g$, $0{ }^{\circ} \mathrm{C}$ ). One millilitre of supernatant was transferred into an HPLC vial. The HPLC setup used to determine carotenoids and chlorophylls consisted of two LC-20AD pumps, a CMB-20A system controller, an SIL-20AC autosampler, an ultraviolet-visible SPD-20AV detector, a CTD-20AC oven and a Max-RP $80 \mathrm{~A}$ column $(250 \times 4.60 \mathrm{~mm})$, which are all Shimadzu products (Polish agent Shimpol, Warsaw, Poland). Methanol + acetonitrile (phase A) and methanol + ethyl acetate (phase B) at a flow rate of $1 \mathrm{~mL} \mathrm{~min}^{-1}$ were used as the gradient solvents (1.00-14.99 $\mathrm{min}, 100 \%$ phase A, 15.00-22.99 $\mathrm{min}$, $40 \%$ phase A; and $24.00-27.00 \mathrm{~min}, 100 \%$ phase A). The wavelength used for detection was $445-450 \mathrm{~nm}$. The carotenoid and chlorophyll concentrations were calculated using standard curves and the sample dilution coefficient and presented in $\mathrm{mg}$ per $100 \mathrm{~g}$ of fresh material. Identified carotenoids and chlorophylls are presented in Figure 4.
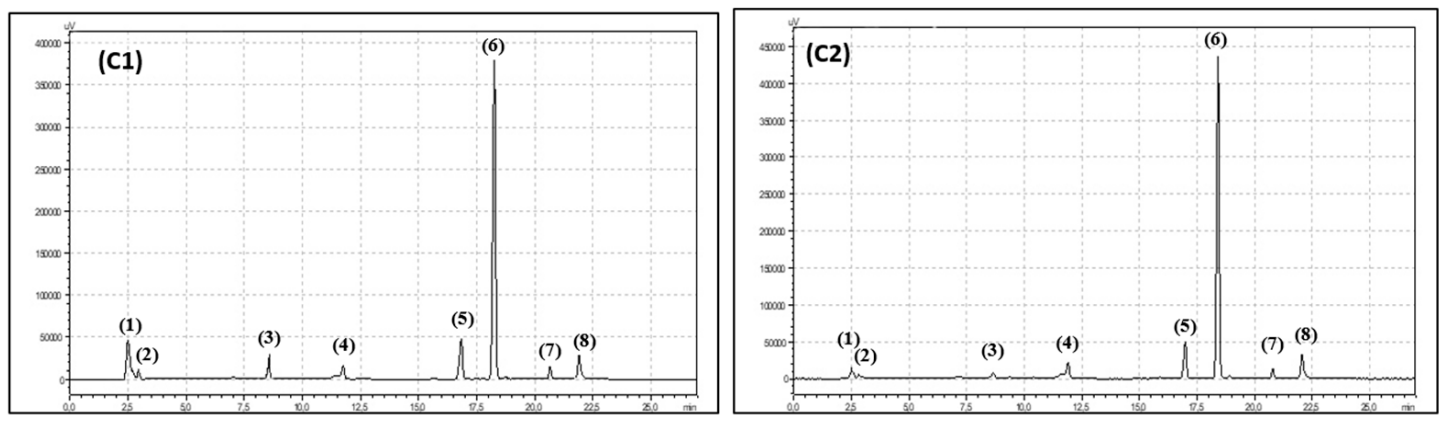

Figure 4. Chromatogram showing retention times for organic raspberry (C1) and conventional raspberry leaves (C2) carotenoids and chllorophylls: (1) lutein, (2) zeaxanthin, (3) neoxanthin, (4) violaxanthin, (5) chlorophyll b, (6) chlorophyll a, (7) alpha-carotene, (8) beta-carotene.

\subsection{ABTS $^{+}$Radical Cation Scavenging Activity Assay}

\subsubsection{ABTS Reagent Preparation}

Twenty milliliters of distilled water was added to $0.0265 \mathrm{~g}$ of potassium persulfate $\left(\mathrm{K}_{2} \mathrm{~S}_{2} \mathrm{O}_{8}\right)$. Five milliliters of distilled water followed by $5 \mathrm{~mL}$ of a previously prepared aqueous solution of potassium persulfate was added to $0.0384 \mathrm{~g}$ of $\mathrm{ABTS}^{+}$(2'2-azinebis-3-ethylbenzothiazolin-6-sulfonic acid) reagent. The solution was prepared a minimum of $12 \mathrm{~h}$ before the planned assay and stored in a dark place. 


\subsubsection{Antioxidant Activity Measurement}

Two-hundred and fifty milligrammes of the sample of freeze-dried plant material tested was weighed into a sterile falcon tube plastic tube with a cap $(50 \mathrm{~mL})$, and $25 \mathrm{~mL}$ of distilled water was added. It was placed onto a vortex shaker (LP shaker Vortex, Labo Plus, Warsaw, Poland) for $60 \mathrm{~s}$ at $2000 \mathrm{rpm}$, for complete mixing. Subsequently, the sample was incubated in a shaker incubator (IKA KS 4000 Control, IKA, Staufen im Breisgau, Germany) for 60 min (temperature $30{ }^{\circ} \mathrm{C}, 6 \times g$ ). After incubation, the sample was again shaken on a vortex shaker for $60 \mathrm{~s}$ for complete mixing and then centrifuged (Centrifuge, MPW-380 R, Warsaw, Poland) at $5{ }^{\circ} \mathrm{C}$ and $14,560 \times g$ for 20 min. After centrifugation, the supernatant was used for determinations. In $10 \mathrm{~mL}$ glass tubes, test extract solution, measured with a predetermined dilution scheme $(0.5-1.5 \mathrm{~mL})$, was then added to $3.0 \mathrm{~mL}$ of ABTS $^{+}$ cationic solution in PBS (phosphate-buffered saline). Absorbance measurements were taken exactly $6 \mathrm{~min}$ after incubation at room temperature. Absorbance was measured at a wavelength $\lambda=734 \mathrm{~nm}$ using a spectrophotometer (Helios $\gamma$, Thermo Scientific, Warsaw, Poland). The obtained measurements were calculated using special formula including the dilution factor. The final results were express as mmol of TE (Trolox equivalents per $100 \mathrm{~g}$ FW (fresh weight of leaves)) [23].

\subsection{Statistical Analysis}

The results obtained from the chemical analyses were statistically analyzed using Statgraphics Centurion 15.2.11.0 software (StatPoint Technologies, Inc., Warranton, VA, USA). The values presented in the tables are expressed as the mean values for the organic and conventional cultivation systems for the five raspberry cultivars ('Polana', 'Polka', 'Tulameen', 'Laszka' and 'Glen Ample'). The mean value for the organic raspberry leaves was obtained from 20 individual measurements $(n=20)$, and the mean value for conventional raspberry leaves was obtained from 24 measurements $(n=24)$. Individual raspberry cultivars were represented as follows: 'Polana' $(n=8)$; 'Tulameen' $(n=8)$; 'Laszka' $(n=8)$; 'Glen Ample' $(n=8)$; 'Polka' $(n=12)$. The statistical calculations were based on two-way analysis of variance with the use of Tukey's test $(p=0.05)$. A lack of statistically significant differences between the examined groups is indicated by similar letters. The standard error (SE) is provided with each mean value reported in the tables.

\section{Results}

\subsection{Polyphenol Content}

The dry matter and polyphenol contents in examined raspberry leaves are presented in Table 2. Organic raspberry leaves were characterized by a significantly higher content of dry matter $(p=0.0055)$ and total polyphenols ( $p=0.0001)$, including total phenolic acids $(p<0.0001)$ as well individual acids: chlorogenic, caffeic and salicylic acids. For flavonoids, we observed that organic plants, compared with conventional plants, contained significantly more quercetin-3-O-rutinoside $(p=0.0009)$. However, raspberry leaves from conventional farming systems contained significantly more luteolin $(p=0.0117)$ than did leaves from organic farming systems.

Raspberry cultivar had a significant impact on the content of phenolic compounds in examined leaves (Table 3). 'Tulameen' cv. was characterized by the highest level of caffeic acid and quercetin derivates, whereas 'Polka' cv. contained the highest and significant levels of ellagic acid ( $\mathrm{p}=0.0046)$. Both of these cultivars contained significantly more quercetin-3-O-glycoside than did the other examined cultivars. The highest luteolin content was found in the leaves of raspberry cultivars 'Polka' and 'Glen Ample'. However, the highest content of quercetin among all analysed cultivars was found in the leaves of raspberry 'Polana' cv. 


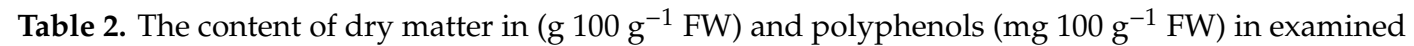
raspberry leaves depending on cultivation system. Data are presented as the mean \pm SE with ANOVA $p$-value.

\begin{tabular}{cccc}
\hline Examined Compounds & $\begin{array}{c}\text { Organic Raspberry } \\
(\boldsymbol{n}=\mathbf{2 0 )}\end{array}$ & $\begin{array}{c}\text { Conventional Raspberry } \\
(\boldsymbol{n}=\mathbf{2 4})\end{array}$ & $p$-Value \\
\hline dry matter & $29.81 \pm 1.26 \mathrm{a}$ & $25.64 \pm 0.73 \mathrm{~b}$ & 0.0055 \\
total polyphenols & $136.10 \pm 6.86 \mathrm{a}$ & $119.95 \pm 14.19 \mathrm{~b}$ & 0.0001 \\
total phenolic acids & $64.09 \pm 3.80 \mathrm{a}$ & $52.94 \pm 6.42 \mathrm{~b}$ & $<0.0001$ \\
chlorogenic & $5.66 \pm 0.57 \mathrm{a}$ & $3.81 \pm 0.50 \mathrm{~b}$ & 0.0188 \\
caffeic & $24.98 \pm 3.32 \mathrm{a}$ & $4.64 \pm 0.82 \mathrm{~b}$ & $<0.0001$ \\
p-coumaric & $14.77 \pm 0.83 \mathrm{~b}$ & $25.02 \pm 3.89 \mathrm{a}$ & 0.0243 \\
ellagic & $15.18 \pm 2.41 \mathrm{a}$ & $16.96 \pm 2.46 \mathrm{a}$ & N.S. \\
salicylic & $3.51 \pm 1.12 \mathrm{a}$ & $2.51 \pm 0.08 \mathrm{~b}$ & $<0.0001$ \\
total flavonoids & $72.01 \pm 3.77 \mathrm{a}$ & $67.01 \pm 7.47 \mathrm{a}$ & N.S. \\
quercetin-3-O-rutinoside & $5.40 \pm 1.12 \mathrm{a}$ & $1.42 \pm 0.34 \mathrm{~b}$ & 0.0009 \\
quercetin-3-O-glucoside & $31.31 \pm 4.13 \mathrm{a}$ & $21.49 \pm 3.55 \mathrm{a}$ & N.S. \\
luteolin & $8.87 \pm 1.43 \mathrm{~b}$ & $20.94 \pm 3.90 \mathrm{a}$ & 0.0117 \\
myrycetin & $7.84 \pm 1.10 \mathrm{a}$ & $6.33 \pm 2.78 \mathrm{a}$ & N.S. \\
quercetin & $18.59 \pm 1.12 \mathrm{a}$ & $16.84 \pm 2.78 \mathrm{a}$ & N.S. \\
\hline
\end{tabular}

${ }^{1}$ Means in rows followed by the same letter are not significantly different at the $5 \%$ level of probability $(p<0.05)$;

${ }^{2}$ N.S. not significant statistically.

Table 3. The content of dry matter in $\left(\mathrm{g} 100 \mathrm{~g}^{-1} \mathrm{FW}\right)$ and polyphenols ( $\left.\mathrm{mg} 100 \mathrm{~g}^{-1} \mathrm{FW}\right)$ in examined raspberry leaves depending on cultivar. Data are presented as the mean \pm SE with ANOVA $p$-value.

\begin{tabular}{|c|c|c|c|c|c|c|}
\hline Examined Compounds & $\begin{array}{l}\text { 'Polana' cv. } \\
\quad(n=8)\end{array}$ & $\begin{array}{l}\text { 'Polka' cv. } \\
(n=12)\end{array}$ & $\begin{array}{l}\text { 'Tulameen' } \\
\text { cv. }(n=8)\end{array}$ & $\begin{array}{l}\text { 'Laszka' cv. } \\
\quad(n=8)\end{array}$ & $\begin{array}{c}\text { 'Glen Ample' } \\
\text { cv. }(n=8)\end{array}$ & $p$-Value \\
\hline dry matter & $26.06 \pm 0.73 \mathrm{a}^{1}$ & $27.77 \pm 1.06 a$ & $29.72 \pm 2.88 \mathrm{a}$ & $28.85 \pm 1.86 a$ & $25.14 \pm 0.81 \mathrm{a}$ & N.S. ${ }^{2}$ \\
\hline total polyphenols & $128.51 \pm 2.78 \mathrm{a}$ & $151.75 \pm 20.67 \mathrm{a}$ & $136.95 \pm 19.10 \mathrm{a}$ & $88.08 \pm 13.17 \mathrm{a}$ & $118.95 \pm 7.48$ & N.S. \\
\hline total phenolic acids & $62.81 \pm 1.83 a$ & $66.55 \pm 8.594 \mathrm{a}$ & $55.55 \pm 11.30 \mathrm{a}$ & $37.35 \pm 7.16 a$ & $63.52 \pm 4.36 a$ & N.S. \\
\hline chlorogenic & $4.46 \pm 0.59 a$ & $5.13 \pm 0.83 a$ & $4.96 \pm 0.17 a$ & $6.04 \pm 1.40 \mathrm{a}$ & $2.44 \pm 0.12 \mathrm{a}$ & N.S. \\
\hline caffeic & $6.56 \pm 1.59 \mathrm{a}$ & $12.60 \pm 1.40 \mathrm{ab}$ & $27.00 \pm 8.70 b$ & $8.61 \pm 3.59 \mathrm{ab}$ & $15.27 \pm 4.99 \mathrm{ab}$ & 0.0401 \\
\hline p-coumaric & $28.81 \pm 6.15 \mathrm{a}$ & $22.67 \pm 5.92 \mathrm{a}$ & $13.92 \pm 1.17 \mathrm{a}$ & $10.10 \pm 2.43 a$ & $25.14 \pm 2.24 \mathrm{a}$ & N.S. \\
\hline ellagic & $20.04 \pm 5.10 \mathrm{ab}$ & $23.22 \pm 3.89 b$ & $6.46 \pm 1.01 \mathrm{a}$ & $9.96 \pm 1.50 \mathrm{a}$ & $17.54 \pm 0.87 \mathrm{ab}$ & 0.0046 \\
\hline salicylic & $2.93 \pm 0.11 \mathrm{a}$ & $2.92 \pm 0.36 a$ & $3.20 \pm 0.36 a$ & $2.65 \pm 0.27 a$ & $3.13 \pm 0.23 a$ & N.S. \\
\hline total flavonoids & $65.71 \pm 2.62 \mathrm{a}$ & $85.19 \pm 12.43 a$ & $81.40 \pm 7.84 a$ & $50.73 \pm 6.37 a$ & $55.43 \pm 3.14 a$ & N.S. \\
\hline $\begin{array}{l}\text { quercetin-3- } \\
\text { O-rutinoside }\end{array}$ & $2.12 \pm 0.17 \mathrm{ab}$ & $4.95 \pm 1.01 \mathrm{ab}$ & $7.05 \pm 2.22 b$ & $0.53 \pm 0.18 \mathrm{a}$ & $0.63 \pm 0.18 a$ & 0.0010 \\
\hline $\begin{array}{l}\text { quercetin-3- } \\
\text { O-glucoside }\end{array}$ & $14.80 \pm 1.10 \mathrm{a}$ & $36.43 \pm 4.95 b$ & $46.88 \pm 6.02 b$ & $13.34 \pm 1.51 \mathrm{a}$ & $13.09 \pm 3.79 a$ & $<0.0001$ \\
\hline luteolin & $3.74 \pm 0.49 a$ & $23.07 \pm 6.61 b$ & $16.14 \pm 1.23 \mathrm{ab}$ & $5.64 \pm 1.22 \mathrm{ab}$ & $24.86 \pm 4.76 b$ & 0.0078 \\
\hline myrycetin & $4.46 \pm 0.42 \mathrm{a}$ & $9.52 \pm 1.79 a$ & $3.09 \pm 0.23 a$ & $8.48 \pm 1.96 a$ & $8.29 \pm 1.91 \mathrm{a}$ & N.S. \\
\hline quercetin & $40.59 \pm 2.21 c$ & $11.23 \pm 0.34 a$ & $8.25 \pm 1.90 \mathrm{a}$ & $22.74 \pm 3.00 b$ & $8.56 \pm 1.38 \mathrm{a}$ & $<0.0001$ \\
\hline
\end{tabular}

${ }^{1}$ Means in rows followed by the same letter are not significantly different at the $5 \%$ level of probability $(p<0.05)$;

${ }^{2}$ N.S. not significant statistically.

\subsection{Carotenoid and Chlorophyll Contents}

The contents of carotenoids and chlorophylls are presented in Table 4. The results showed that raspberry leaves from conventional farming contained significantly more total carotenoids $(p=0.0014)$,

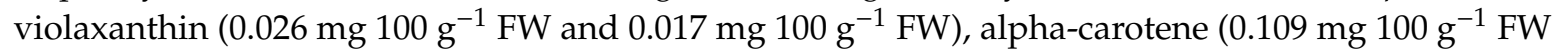
and $\left.0.060 \mathrm{mg} 100 \mathrm{~g}^{-1} \mathrm{FW}\right)$ and beta-carotene $\left(1.22 \mathrm{mg} 100 \mathrm{~g}^{-1} \mathrm{FW}\right.$ and $\left.0.46 \mathrm{mg} 100 \mathrm{~g}^{-1} \mathrm{FW}\right)$ than did the leaves from organic farming; however, the leaves from conventional farming contained significantly less neoxanthin $(p=0.003)$, lutein $(p=0.0069)$ and zeaxanthin $(p=0.0118)$. Moreover, leaves from conventional farming, compared to leaves from organic farming, were characterized by higher contents

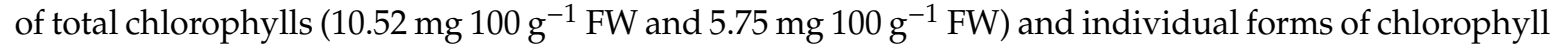
( $a$ and $b)$. Cultivar had a significant impact only on neoxanthin $(p<0.0001)$ content in leaves. 'Laszka' cv. contained significantly more of this xanthophyll among all analysed cultivars (Table 5). 
Table 4. The content of carotenoids (mg $100 \mathrm{~g}^{-1} \mathrm{FW}$ ) and chlorophylls ( $\mathrm{mg} 100 \mathrm{~g}^{-1} \mathrm{FW}$ ) in examined raspberry leaves depending on cultivation system. Data are presented as the mean \pm SE with ANOVA $p$-value.

\begin{tabular}{cccc}
\hline Examined Compounds & $\begin{array}{c}\text { Organic Raspberry } \\
(\boldsymbol{n}=\mathbf{2 0 )}\end{array}$ & $\begin{array}{c}\text { Conventional Raspberry } \\
(\boldsymbol{n}=\mathbf{2 4})\end{array}$ & $p$-Value \\
\hline total carotenoids & $2.61 \pm 0.12 \mathrm{~b}$ & $3.14 \pm 0.10 \mathrm{a}$ & 0.0014 \\
neoxanthin & $0.045 \pm 0.01 \mathrm{a}$ & $0.025 \pm 0.00 \mathrm{~b}$ & 0.0013 \\
lutein & $1.23 \pm 0.05 \mathrm{a}$ & $1.06 \pm 0.03 \mathrm{~b}$ & 0.0069 \\
zeaxanthin & $0.80 \pm 0.03 \mathrm{a}$ & $0.70 \pm 0.02 \mathrm{~b}$ & 0.0118 \\
violaxanthin & $0.017 \pm 0.001 \mathrm{~b}$ & $0.026 \pm 0.002 \mathrm{a}$ & 0.0004 \\
alpha-carotene & $0.060 \pm 0.01 \mathrm{~b}$ & $0.109 \pm 0.01 \mathrm{a}$ & 0.0001 \\
beta-carotene & $0.46 \pm 0.03 \mathrm{~b}$ & $1.22 \pm 0.06 \mathrm{a}$ & $<0.0001$ \\
total chlorophylls & $5.75 \pm 0.30 \mathrm{~b}$ & $10.52 \pm 0.60 \mathrm{a}$ & $<0.0001$ \\
chlorophyll b & $1.79 \pm 0.08 \mathrm{~b}$ & $2.43 \pm 0.12 \mathrm{a}$ & 0.0001 \\
chlorophyll a & $3.96 \pm 0.23 \mathrm{~b}$ & $8.09 \pm 0.48 \mathrm{a}$ & $<0.0001$ \\
chlorophyll a/b & $2.19 \pm 0.06 \mathrm{~b}$ & $3.29 \pm 0.05 \mathrm{a}$ & $<0.0001$ \\
\hline
\end{tabular}

${ }^{1}$ Means in rows followed by the same letter are not significantly different at the $5 \%$ level of probability $(p<0.05)$.

Table 5. The content of carotenoids ( $\mathrm{mg} 100 \mathrm{~g}^{-1} \mathrm{FW}$ ) and chlorophylls ( $\mathrm{mg} 100 \mathrm{~g}^{-1} \mathrm{FW}$ ) in examined raspberry leaves depending on cultivar. Data are presented as the mean \pm SE with ANOVA $p$-value.

\begin{tabular}{|c|c|c|c|c|c|c|}
\hline Examined Compounds & $\begin{array}{l}\text { 'Polana' cv. } \\
\quad(n=8)\end{array}$ & $\begin{array}{c}\text { 'Polka' cv. } \\
(n=12)\end{array}$ & $\begin{array}{l}\text { 'Tulameen' } \\
\text { cv. }(n=8)\end{array}$ & $\begin{array}{c}\text { 'Laszka' cv. } \\
\quad(n=8)\end{array}$ & $\begin{array}{l}\text { 'Glen Ample' } \\
\text { cv. }(n=8)\end{array}$ & $p$-Value \\
\hline total carotenoids & $2.70^{1} \pm 0.07 a$ & $3.00 \pm 0.22 \mathrm{a}$ & $2.88 \pm 0.19 a$ & $3.17 \pm 0.12 \mathrm{a}$ & $2.72 \pm 0.22 \mathrm{a}$ & N.S. ${ }^{2}$ \\
\hline neoxanthin & $0.033 \pm 0.00 \mathrm{a}$ & $0.024 \pm 0.00 \mathrm{a}$ & $0.037 \pm 0.01 \mathrm{a}$ & $0.062 \pm 0.01 b$ & $0.021 \pm 0.00 \mathrm{a}$ & $<0.0001$ \\
\hline lutein & $1.08 \pm 0.03 a$ & $1.15 \pm 0.04 \mathrm{a}$ & $1.23 \pm 0.12 \mathrm{a}$ & $1.19 \pm 0.08 \mathrm{a}$ & $1.05 \pm 0.03 a$ & N.S. \\
\hline zeaxanthin & $0.70 \pm 0.02 \mathrm{a}$ & $0.75 \pm 0.03 a$ & $0.80 \pm 0.08 \mathrm{a}$ & $0.79 \pm 0.05 a$ & $0.68 \pm 0.02 \mathrm{a}$ & N.S. \\
\hline violaxanthin & $0.024 \pm 0.002 \mathrm{a}$ & $0.024 \pm 0.002 \mathrm{a}$ & $0.018 \pm 0.001 \mathrm{a}$ & $0.017 \pm 0.001 \mathrm{a}$ & $0.025 \pm 0.004 \mathrm{a}$ & N.S. \\
\hline alpha-carotene & $0.070 \pm 0.01 \mathrm{a}$ & $0.088 \pm 0.01 \mathrm{a}$ & $0.100 \pm 0.01 \mathrm{a}$ & $0.095 \pm 0.02 \mathrm{a}$ & $0.080 \pm 0.02 \mathrm{a}$ & N.S. \\
\hline beta-carotene & $0.79 \pm 0.09 a$ & $0.96 \pm 0.14 \mathrm{a}$ & $0.70 \pm 0.04 \mathrm{a}$ & $1.01 \pm 0.18 \mathrm{a}$ & $0.87 \pm 0.20 \mathrm{a}$ & N.S. \\
\hline total chlorophylls & $7.64 \pm 0.35 a$ & $9.13 \pm 1.06 a$ & $6.73 \pm 0.30 \mathrm{a}$ & $9.62 \pm 1.44 \mathrm{a}$ & $8.25 \pm 1.49 a$ & N.S. \\
\hline chlorophyll b & $1.95 \pm 0.04 a$ & $2.23 \pm 0.19 a$ & $1.93 \pm 0.14 \mathrm{a}$ & $2.45 \pm 0.21 a$ & $2.10 \pm 0.26 a$ & N.S. \\
\hline chlorophyll a & $5.69 \pm 0.31 a$ & $6.90 \pm 0.87 a$ & $4.81 \pm 0.17 \mathrm{a}$ & $7.17 \pm 1.23 \mathrm{a}$ & $6.15 \pm 1.24 \mathrm{a}$ & N.S. \\
\hline chlorophyll a/b & $2.91 \pm 0.11 \mathrm{a}$ & $2.93 \pm 0.17 a$ & $2.56 \pm 0.11 \mathrm{a}$ & $2.75 \pm 0.27 a$ & $2.71 \pm 0.27 a$ & N.S. \\
\hline
\end{tabular}

${ }^{1}$ Means in rows followed by the same letter are not significantly different at the $5 \%$ level of probability $(p<0.05)$;

${ }^{2}$ N.S. not significant statistically.

\subsection{Antioxidant Activity}

Organic raspberry leaves, compared with leaves from conventional farming, were characterized by significantly higher antioxidant activity $(p<0.0001)$ (Figure 5). Among the group of examined raspberry cultivars, the strongest antioxidant potential shown was in 'Polka' cv. and 'Tulameen' cv. There was a significant correlation between antioxidant activity in vitro and the total polyphenol content in examined raspberry leaves (Figure 6). The stronger antioxidant activity in the leaves was a reflection of higher content of polyphenols, especially in the organic plants $\left(R^{2}=0.8302, p<0.0001\right)$. 


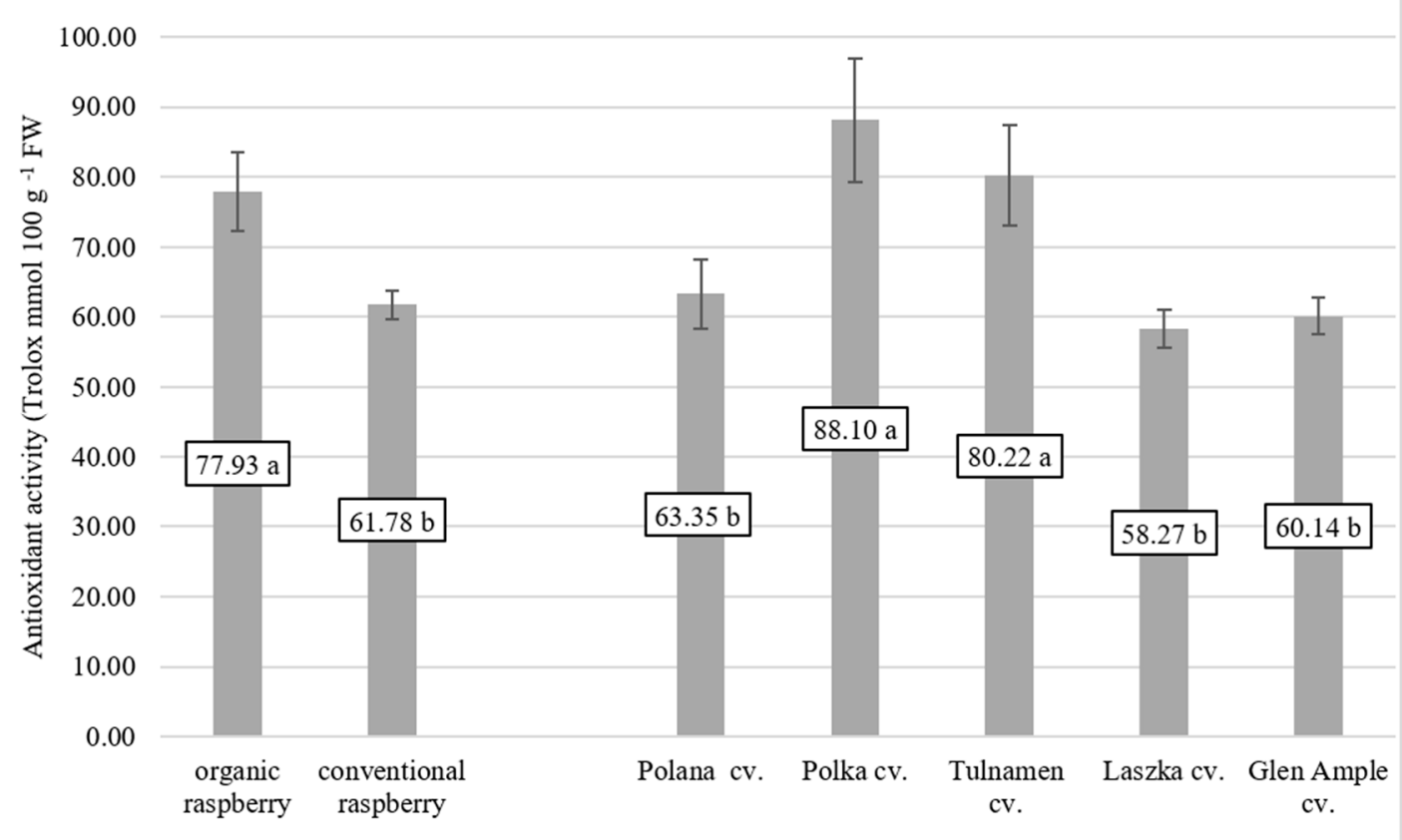

Figure 5. Antioxidant activity raspberry from organic and conventional cultivation $(p<0.0001)$ and raspberry cultivars $(p<0.0001)$. Means followed by the same letter are not significantly different $(p<0.05)$.
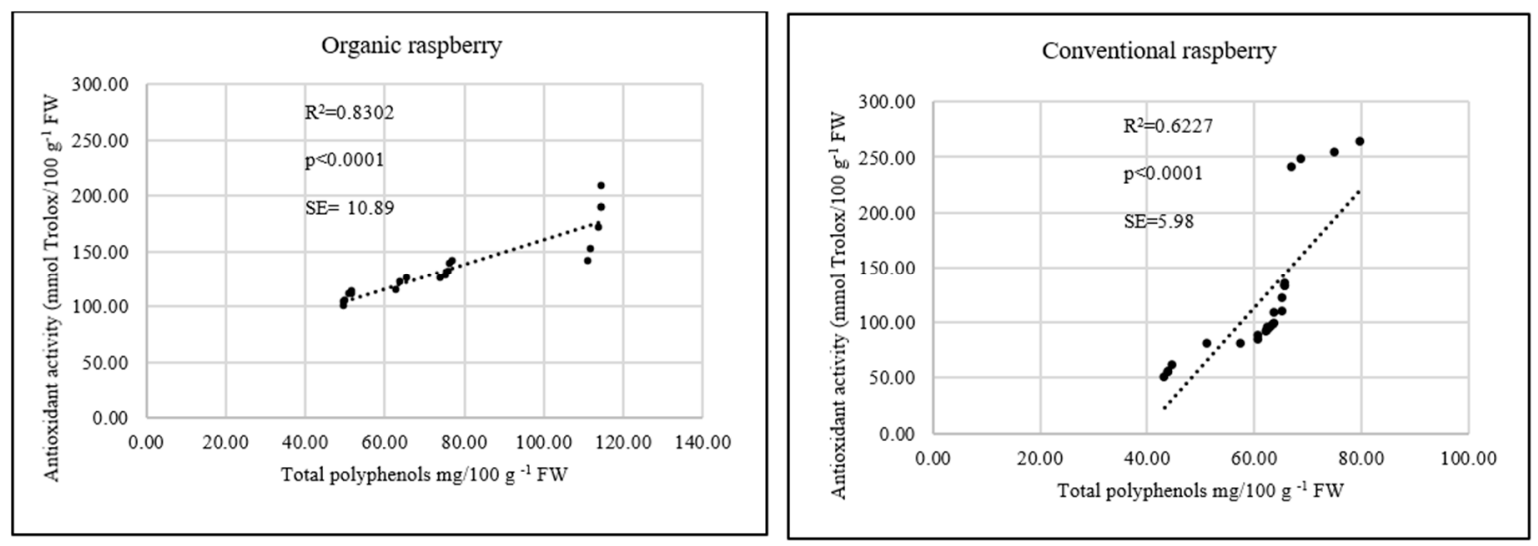

Figure 6. Linear regression (Pearson's coefficient $\mathrm{R}^{2}$ ) between antioxidant activity and total polyphenols in organic $(n=20)$ and conventional $(n=24)$ raspberry leaves.

\section{Discussion}

Berry fruits are recognized worldwide as "superfoods" due to the high content of bioactive compounds and their health benefits [24-27]. Most research on the impact of the cultivation system (organic and conventional) on the quality of raspberries concerns fruit $[15,18]$. As the literature shows, only little attention has been paid to biologically active substances in leaves, which was the research material in this study. Their traditional therapeutic use against several diseases, such as the cold, inflammation, diabetes and ocular dysfunction, has almost been forgotten. Raspberry leaves are a powerful source of biologically active compounds (Tables 2-5). The high content of bioactive compounds means that infusions of raspberry leaves can be used in phytotherapy [5]. Only a few studies have shown the antioxidant properties and polyphenol content in raspberry leaves. In our analysis, we found that organic raspberry leaves, compared with conventional raspberry leaves, were characterized by significantly higher contents of total polyphenols, total phenolic acids, chlorogenic 
acid, caffeic acid, salicylic acid and quercetin-3-O-rutinoside. In our experiment, we found $136.1 \mathrm{mg}$

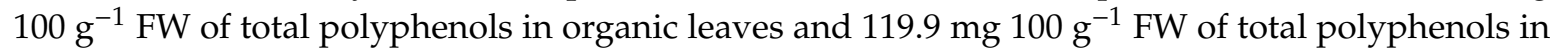
conventional leaves. Teleszko \& Wojdyło [28] described similar results. Their research showed that the leaves of berries were not only a valuable source of antioxidants but also contained significantly more polyphenols than did the fruit. This clearly indicates that plant parts other than the fruits could be used for medical or food purposes. An example of their application is herbal tea. The main compound of polyphenols found in raspberry leaves is salicylic acid. We found $3.51 \mathrm{mg} 100 \mathrm{~g}^{-1} \mathrm{FW}$ of salicylic acid in the studied organic raspberry leaves. Salicylic acid is synthesized by plants as a response to abiotic stresses, such as osmotic stress, chilling, drought and heat [13,14,29] As reported by Nour, Trandafir \& Cosmulescu [9], seven cultivars of blackcurrant contain salicylic acid in the leaves, ranging from

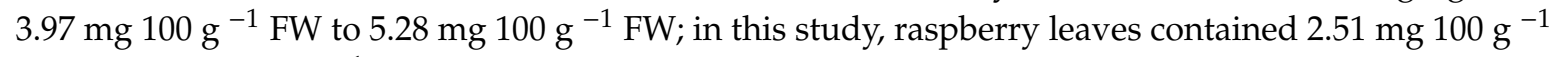

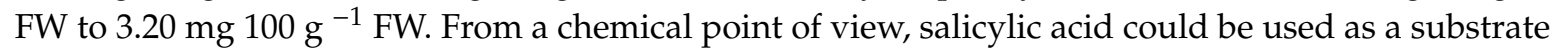
for acetylic reactions and acetylsalicylic acid formation. The manifold effects of acetyl salicylic acid on human physiology can potentially provide health benefits [30]. One of the important phenolic acids extracted from the Rubus family is ellagic acid. As reported by Landete [10] raspberry fruits contain ellagic acid in a wide rate: $47-270 \mathrm{mg} 100 \mathrm{~g}^{-1} \mathrm{FW}$. In a study by Oszmiański et al. [1] the ellagic

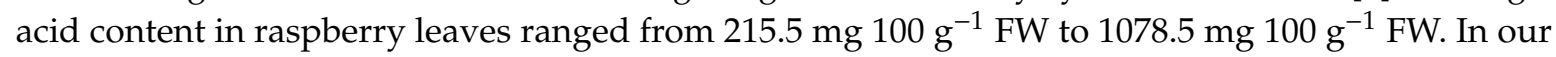
experiment, we found much lower levels of ellagic acid but were still satisfied (Tables 2 and 3).

A very important group of compounds present in raspberry leaves is flavonoids. The quantity of flavonoids in the leaves of raspberries is significantly higher than that in the fruits, where flavonoids compose only a very small fraction of the bioactive compounds [31]. In a study by Oszmiański et al. [1] the flavonoid fraction was the main phenolic group, constituting almost $11 \%$ of leaf extract powder weight. In our experiment, we identified 5 flavonoid compounds, quercetin-3-O-rutinoside, quercetin-3-O-glucoside, luteolin, myricetin and quercetin, in examined raspberry leaves. However, Buricova et al. [32] examined antioxidant capacity and antioxidants in raspberry leaf water extract, and three flavonoid compounds were detected (catechin, epicatechin and procyanidin $\mathrm{B}_{1}$ ), while Ferlemi \& Lamari [5] detected much more flavonoid compounds present in raspberry leaves (quercetin, quercetin-3-O-rutinoside, quercetin-3-O-galactoside, quercetin-3-O-glucoside, quercetin-3-O-glucuronide, kaempferol-3-O-glucoside, epicatechin gallate methyl gallate, sanguiin $\mathrm{H}-6 /$ lambertianin $\mathrm{C}$ and lambertianin D). In contrast, in an analysis by Oszmiański et al. [1] thirty-three phenolic compounds were detected in wild blackberry leaf samples (fifteen flavonols, thirteen hydroxycinnamic acids, three ellagic acid derivatives and two flavones). Flavonoids have antioxidant abilities and protect plants from various biotic and abiotic stresses. The role of secondary metabolic pathways in plant responses is to cope with oxidative stress, resulting in the synthesis of flavonoids [33]. Another important role of flavonoids in foliar plants is their action as a screen against severe sunlight illumination [34]. One of the most important priorities in research on polyphenolic compound content is not just determining their presence but also biological activity in vitro and in vivo. Dudzińska et al. [35] investigated the polyphenol content in raspberry leaves and their antioxidative power. The antioxidant capacities of the examined extracts remained relatively high and corresponded well to the determined total polyphenol content. As pointed out by Oszmiański et al. [1] the antioxidant power of raspberry leaves is strongly connected with the total polyphenol content. They measured total phenolic content and antioxidant activity (AA) of 27 species belonging to the Rubus family. They found a significant link between the highest polyphenolic concentration and AA of raspberry leaves. The species with the highest total polyphenol content also had the highest antioxidant activity: Rubus pedemontanus

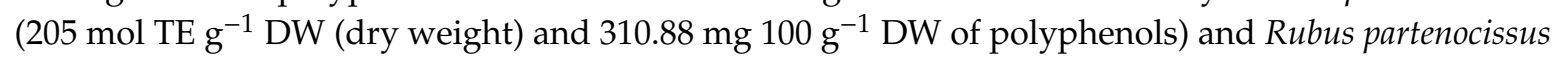

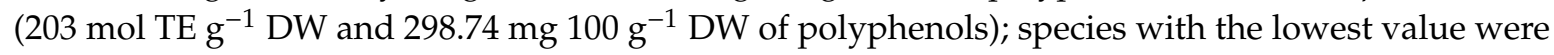
characterized by the lowest antioxidant power: Rubus radula ( $151 \mathrm{~mol} \mathrm{TE} \mathrm{g}^{-1} \mathrm{DW}$ and $202.21 \mathrm{mg}^{100 \mathrm{~g}^{-1}}$

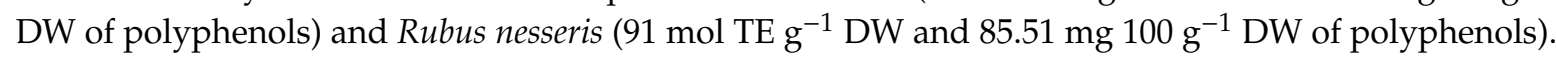
In our study, we observed the highest levels of total polyphenols in 'Polka' cv. (151.75 mg $100 \mathrm{~g}^{-1}$ FW) and 'Tulameen' cv. (136. $95 \mathrm{mg} 100 \mathrm{~g}^{-1} \mathrm{FW}$ ). Those levels were reflected in their antioxidant 
status ( $88.10 \mathrm{mmol}$ Trolox $100 \mathrm{~g}^{-1} \mathrm{FW}$ and $80.22 \mathrm{mmol}$ Trolox $100 \mathrm{~g}^{-1} \mathrm{FW}$ ) and significant correlation between features $\left(R^{2}=0.8302, p<0.0001\right)$ for the organic raspberry but much weaker correlation for the conventional raspberry $\left(R^{2}=0.6227, p<0.0001\right)$ (Figure 6). Similar results were described by Zlotek et al. with basil leaves [36]. The antioxidant status of leaves was positively correlated with polyphenols content [37].

In addition to the presence of photosynthetic pigments, carotenoids also exist in raspberry leaves. Their concentration in leaves depends mainly on the level of chlorophyll. The higher the concentration of chlorophyll in the leaves, the more carotenoids present. Chlorophyll is associated with the function of carotenoids, which are produced by plants mainly to protect the photosynthetic system against photooxidation. Carotenoids are synthesized via the general biosynthetic pathway within the chloroplasts of plants. Shen et al. [38] also studied the effect of increased UV-B radiation on carotenoid accumulation and total antioxidant capacity in tobacco (Nicotiana tabacum L.) leaves. Higher levels of chlorophylls were positively correlated with beta-carotene content. In our experiment, we observed similar results. Conventional raspberry with a significant chlorophyll level $\left(2.43 \mathrm{mg} 100 \mathrm{~g} \mathrm{~g}^{-1} \mathrm{FW}\right)$ contained a significant level of total carotenoids ( $3.14 \mathrm{mg} 100 \mathrm{~g}^{-1} \mathrm{FW}$ ) compared to that of organic

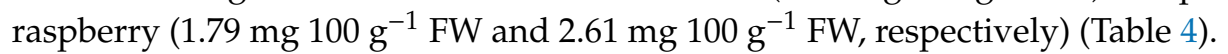

\section{Conclusions}

In summary, the aim of the study was reached and confirmed. Raspberry leaves are a valuable source of bioactive compounds. Moreover, compared to conventional leaves, organic raspberry leaves were characterized by a significantly higher content of total polyphenols, total phenolic acids, chlorogenic acid, caffeic acid, salicylic acid and quercetin-3-O-rutinoside. Additionally, the organic leaves had higher antioxidant activity; the strongest antioxidant potential was shown by the 'Polka' and 'Tulameen' cultivars. On the other hand, raspberry leaves from conventional farms contained more total carotenoids, violaxanthin, alpha-carotene, beta-carotene, total chlorophyll and individual forms of chlorophyll ( $a$ and $b$ ). The mineral fertilization used in conventional agriculture increases the level of these compounds.

Author Contributions: Conceptualization, E.H.; data curation, E.H.; formal analysis A.P.; funding acquisition E.H.; methodology, A.P. and E.H.; project administration E.H.; resources A.P.; software A.P.; supervision E.H.; validation E.H.; visualization A.P.; writing original draft A.P.; writing review \& editing A.P. and E.H.

Funding: This research received no external funding.

Acknowledgments: This paper has been published under the support of the Polish Ministry of Higher Education within the foundation of the Institute of Human Nutrition, Warsaw University of Life Sciences (WULS), for scientific research.

Conflicts of Interest: The authors declare no conflict of interest.

\section{References}

1. Oszmiański, J.; Wojdyło, A.; Gorzelany, J.; Kapusta, I. Identification and characterization of low molecular weight polyphenols in berry leaf extracts by HPLC-DAD and LC-ESI/MS. J. Agric. Food Chem. 2011, 59, 12830-12835. [CrossRef] [PubMed]

2. Costea, T.; Lupu, A.R.; Vlase, L.; Nencu, I.; Gîrd, C.E. Phenolic content and antioxidant activity of a raspberry leaf dry extract. Rom. Biotechnol. Lett. 2016, 21, 11345-11356.

3. Grochowski, D.M.; Paduch, R.; Wiater, A.; Dudek, A.; Pleszczyńska, M.; Tomczykowa, M.; Granica, S.; Polak, P.; Tomczyk, M. In vitro antiproliferative and antioxidant effects of extracts from Rubus caesius leaves and their quality evaluation. Evid. Based Complement Alternat Med. 2016, 2016, 1-8. [CrossRef] [PubMed]

4. Veljković, B.; Đorđević, N.; Dolićanin, Z.; Ličina, B.; Topuzović, M.; Stanković, M.; Zlatić, N.; Dajić-Stevanović, Z. Antioxidant and anticancer properties of leaf and fruit extracts of the wild raspberry (Rubus idaeus L.). Not. Bot. Hortic. Agrobot. 2019, 47, 359-367. [CrossRef]

5. Ferlemi, A.V.; Lamari, F.N. Berry leaves: An alternative source of bioactive natural products of nutritional and medicinal value. Antioxidants 2016, 5, 17. [CrossRef] [PubMed] 
6. Kratchanova, M.; Denev, P.; Ciz, M.; Lojek, A.; Mihailov, A. Evaluation of antioxidant activity of medicinal plants containing polyphenol compounds. Comparison of two extraction systems. Acta Biochim. Pol. 2010, 57, 229-234. [CrossRef] [PubMed]

7. Han, N.; Gu, Y.; Ye, C.; Cao, Y.; Liu, Z.; Yin, J. Antithrombotic activity of fractions and components obtained from raspberry leaves (Rubus chingii). Food Chem. 2012, 132, 181-185. [CrossRef]

8. Pavlović, A.V.; Papetti, A.; Dabić Zagorac, D.Č.; Gašić, U.M.; Mišić, D.M.; Tešić, Ž.; Natić, M.M. Phenolics composition of leaf extracts of raspberry and blackberry cultivars grown in Serbia. Ind. Crop. Prod. 2016, 87, 304-314. [CrossRef]

9. Nour, V.; Trandafir, I.; Cosmulescu, S. Antioxidant capacity, phenolic compounds and minerals content of blackcurrant (Ribes nigrum L.) leaves as influenced by harvesting date and extraction method. Ind. Crop. Prod. 2014, 53, 133-139. [CrossRef]

10. Landete, J.M. Ellagitannins, ellagic acid and their derived metabolites: A review about source, metabolism, functions and health. Food Res. Int. 2011, 44, 1150-1160. [CrossRef]

11. Rishton, G.M. Natural products as a robust source of new drugs and drug leads: Past successes and present day issues. Am. J. Cardiol. 2008, 101, 43-49. [CrossRef] [PubMed]

12. Moschona, A.; Kyriakidis, K.D.; Kleontas, A.D.; Liakopoulou-Kyriakides, M. Comparative study of natural phenolic acids and flavonols as antiplatelet and anti-inflammatory agents. Grant Med. J. 2017, 2, 54-66.

13. Vlot, A.C.; Dempsey, D.M.A.; Klessig, D.F. Salicylic acid, a multifaceted hormone to combat disease. Annu. Rev. Phytopathol. 2009, 47, 177-206. [CrossRef] [PubMed]

14. Rivas-San Vicente, M.; Plasencia, J. Salicylic acid beyond defence: Its role in plant growth and development. J. Exp Bot. 2011, 62, 3321-3338. [CrossRef]

15. Skupień, K.; Ochniam, I.; Grajkowski, J.; Krzywy-Gawrońska, E. Nutrients, antioxidants, and antioxidant activity of organically and conventionally grown raspberries. J. Appl Bot. Food Qual. 2011, 84, 85-89.

16. Crecente-Campo, J.; Nunes-Damaceno, M.; Romero-Rodríguez, M.A.; Vázquez-Odériz, M.L. Color, anthocyanin pigment, ascorbic acid and total phenolic compound determination in organic versus conventional strawberries (Fragaria x ananassa Duch, cv Selva). J. Food Compos. Anal. 2012, 28, $23-30$. [CrossRef]

17. Tassoni, A.; Tango, N.; Ferri, M. Comparison of biogenic amine and polyphenol profiles of grape berries and wines obtained following conventional, organic and biodynamic agricultural and oenological practices. Food Chem. 2013, 139, 405-413. [CrossRef]

18. Ponder, A.; Hallmann, E. The effects of organic and conventional farm management and harvest time on the polyphenol content in different raspberry cultivars. Food Chem. 2019, 301. [CrossRef]

19. Rempelos, L.; Almuayrifi, A.M.; Baranski, M.; Tetard-Jones, C.; Eyre, M.; Shotton, P.; Cakmak, I.; Ozturk, L.; Cooper, J.M.; Volakakis, N.; et al. Effects of agronomic management and climate on leaf phenolic profiles, disease severity and grain yield in organic and conventional wheat production systems. J. Agric. Food Chem. 2018. [CrossRef]

20. Vagiri, M.; Johansson, E.; Rumpunen, K. Phenolic compounds in black currant leaves-An interaction between the plant and foliar diseases? J. Plant Interact. 2017, 12, 193-199. [CrossRef]

21. Ohene, I.; Maalekuu, B.K. Effect of some postharvest treatments on the quality and shelf life of three cultivars of carrot (Daucus carota L.) during storage at room temperature. Am. J. Clin Nutr. 2013, 3, 64-72.

22. Hallmann, E.; Rozpara, E.; Słowianek, M.; Leszczyńska, J. The effect of organic and conventional farm management on the allergenic potency and bioactive compounds status of apricots (Prunus armeniaca $\mathrm{L}$ ). Food Chem. 2019, 279, 171-178. [CrossRef]

23. Re, R.; Pellegrini, N.; Proteggente, A.; Nala, A.; Yang, M.; Rice-Evans, C. Antioxidant activity applying an improved ABTS radical cation decolorization assay. Free Radic. Biol. Med. 1999, 26, 1231-1237. [CrossRef]

24. Gutierrez-Albanchez, E.; Kirakosyan, A.; Bolling, S.F.; García-Villaraco, A.; Gutierrez-Mañero, J.; Ramos-Solano, B. Biotic elicitation as a tool to improve berry (Strawberry and Raspberry) extract potential on metabolic syndrome related enzymes in vitro. J. Sci. Food Agric. 2018. [CrossRef]

25. Wu, T.; Yang, L.; Guo, X.; Zhang, M.; Liu, R.; Sui, W. Raspberry anthocyanin consumption prevents diet-induced obesity by alleviating oxidative stress and modulating hepatic lipid metabolism. Food Funct. 2018, 9, 2112-2120. [CrossRef] 
26. Chen, L.; Li, K.; Liu, Q.; Quiles, J.L.; Filosa, R.; Kamal, M.A.; Wang, F.; Kai, G.; Xiao, J. Protective effects of raspberry on the oxidative damage in HepG2 cells through Keap1/Nrf2-dependent signaling pathway. Food Chem. Toxicol. 2019, 133, 110781. [CrossRef] [PubMed]

27. Krga, I.; Milenkovic, D. Anthocyanins: From sources and bioavailability to cardiovascular health benefits and molecular mechanisms of action. J. Agric. Food Chem. 2019. [CrossRef]

28. Teleszko, M.; Wojdyło, A. Comparison of phenolic compounds and antioxidant potential between selected edible fruits and their leaves. J. Funct. Foods 2015, 14, 736-746. [CrossRef]

29. Chen, Z.; Zheng, Z.; Huang, J.; Lai, Z.; Fan, B. Biosynthesis of salicylic acid in plants. Plant Signal. Behav. 2009, 4, 493-496. [CrossRef]

30. Sayyari, M.; Castillo, S.; Valero, D.; Díaz-Mula, H.M.; Serrano, M. Acetyl salicylic acid alleviates chilling injury and maintains nutritive and bioactive compounds and antioxidant activity during postharvest storage of pomegranates. Postharvest Biol. Technol. 2011, 60, 136-142. [CrossRef]

31. Gudej, J. Kaemferol and quercetin glycosides from Rubus idaeus L. leaves. Acta Pol. Pharm. 2003, 60, 313-316. [PubMed]

32. Buricova, L.; Andjelkovic, M.; Cermakova, A.; Reblova, Z.; Jurcek, O.; Kolehmainen, E.; Verhe, R.; Kvasnicka, F. Antioxidant capacities and antioxidants of strawberry, blackberry and raspberry leaves. Czech. J. Food Sci. 2011, 29, 181-189. [CrossRef]

33. Grace, S.C.; Logan, B.A. Energy dissipation and radical scavenging by the plant phenyl propanoid pathway. Philos. Trans. R. Soc. Lond. Ser. B Biol. Sci. 2000, 355, 1499-1510. [CrossRef] [PubMed]

34. Behn, H.; Schurr, U.; Ulbrich, A.; Noga, G. Development-dependent UV-B responses in red oak leaf lettuce (Lactuca sativa L.): Physiological mechanisms and significance for hardening. Eur. J. Hortic. Sci. 2011, 76, 33.

35. Dudzinska, D.; Luzak, B.; Boncler, M.; Rywaniak, J.; Sosnowska, D.; Podsedek, A.; Watala, C. CD39/NTPDase-1 expression and activity in human umbilical vein endothelial cells are differentially regulated by leaf extracts from Rubus caesius and Rubus idaeus. Cell Mol. Biol. Lett. 2014, 19, 361-380. [CrossRef] [PubMed]

36. Złotek, U.; Mikulska, S.; Nagajek, M.; Świeca, M. The effect of different solvents and number of extraction steps on the polyphenol content and antioxidant capacity of basil leaves (Ocimum basilicum L.) extracts. Saudi J. Biol. Sci. 2016, 23, 628-633. [CrossRef]

37. Rafiee, Z.; Jafari, S.M.; Alami, M.; Khomeiri, M. Antioxidant effect of microwave-assisted extracts of olive leaves on sunflower oil. J. Agric. Sci. Technol. 2012, 14, 1497-1509.

38. Shen, J.; Jiang, C.; Yan, Y.; Liu, B.; Zu, C. Effect of increased UV-B radiation on carotenoid accumulation and total antioxidant capacity in tobacco (Nicotiana tabacum L.) leaves. Genet. Mol. Res. 2017, 16, 1-11. [CrossRef] 